\title{
The United States of America - A Declining World Hegemon?
}

\author{
Benjamin Klasche, M.A., PhD-Candidate \\ Tallinn University, School of Governance, Law and Society, Estonia
}

Doi:10.19044/esj.2018.v14n17p46 URL:http://dx.doi.org/10.19044/esj.2018.v14n17p46

\begin{abstract}
In this article the alleged demise of the United States of America (USA) and the ability of its challengers will be discussed and analyzed. Based on George Modelski's concept of Long-Cycles in Global Politics we can anticipate a disruption in the hegemonic position - currently held by the USA. Considering, the possibility of this scenario, the author executed a pragmatic comparative study and sketches out the chances for the two main competitors - China and India - which struggle mightily with domestic issues and on the other side presents four arguments, why the decline of the USA is not as apparent and looming as partly presumed. The arguments are: (i) the independence supply of natural resources; (ii) its supremacy over the world seas; (iii) reinstated activity in the Rimland and (iiii) control over the Global Commons.
\end{abstract}

Keywords: International Relations, World Hegemon, Brics, Rimland, Global Commons

\section{Introduction}

The international (and in many cases national) politics in last century have been dominated by the United States of America (USA). The United States (US) have gained this status with its victorious involvement in the Second World War (Wallerstein, 2003) or latest with the end of the Cold War, when it became the sole superpower in the world. In this period, it played an important role in maintaining world order, secured a framework for international transactions with its currency (Mandelbaum, 2006). These positive aspects of fulfilling a world governance role are also accompanied by more negative ones which evolve around the mingling of domestic issues of other states culminating in military interventions (e.g. Meernik, 2004). Nevertheless, at the current point of time, the US seems to remain in this position. However, latest with the election of President Trump the question 
whether the time of its hegemony is over, can be asked again. ${ }^{1}$ Is the US a staggering giant that just waits to be tipped over by the Republic of China or a combination of new rising powers? Next to the extremely quickly growing economies and populations in China and India one can swiftly revering to the financial crisis of 2008, the divided population, several unsuccessful military interventions and Russia's seemingly successful stand up in the Ukraine Crisis when it comes to the symptoms of America's decline. It is not possible to ignore these facts when one tries to diagnose US' capability of keeping its position. However, a sharp reader might have been guessed, that opinion these factors might only gradually influence and shape the outcome of the upcoming years, decades or even centuries. The US' decline is not at all as obvious as it might be presented. Several factors, such as the uncontested domination of the world oceans, the complete domination of the latest global common - the internet, its shaping ability to supply itself with fossil energy, and lastly its soon to be reintroduced influence in the Rimland. The United States is virtually uncatchable in these fields in the next century. All these aspects will be analysed below.

Next to the US' persisting dominance and exertion of influence one has also consider the potential of the contestants to take over and fulfil the requirements of a world hegemon. Most recently the BRICS (Brazil, Russia, India, China, South-Africa) coalition gets identified as the only real threat for the US' throne (e.g. Hung, 2017:639). Even though at the moment equipped with limited political power the organization combines four of the fastest growing economies and an old superpower that wants to regain its position at the top of the international order. ${ }^{2}$ It is hard to asses, which power this coalition will possess in the future but it appears more a question of where China and India want to go instead of what a BRICS coalition would be able to achieve. Both of them had absolutely staggering economic growth rates in the past $^{3}$ and will most likely continue to grow in a similar manner. They boast the biggest populations in the world and are also aware of their potential place in the world. Potential is also the factor, where those two stand out in this group and therefore the reason why I reckon to focus on these two when it comes to competitors of the US hegemonic position. The bygone developments of India and China are obviously undeniable and very

\footnotetext{
${ }^{1}$ Also asked here: Layne 2009, Komlosy, 2016.

2 Where India's and China's extreme growth is beyond doubt, Brazil and South Africa had a rather stagnated growth rates in the last three years (Brazil: between $1.0 \%$ and $2.7 \%$, S.-A.: $1.9 \%$ and 3.1\%). Russia's growth rates except for $2013(0.7 \%)$ are also pointing on a significant economic growth (World Bank, 2014). However, it is not really an emerging power, due to its history.

They found themselves in the high single digit area after years and years of double digit growth rate.
} 
impressive, but are we not a little bit quick to assume that the future development will continue in a similar smooth and successful way? Even if the projections are being fulfilled and China's and India's economy will overcome the US' one it is not being said that this will be enough to contest US's position. Moreover, the Asian powers have to overcome several growing pains in the process that are endangering the continued positive development. In the near future both countries have to take care of increasing domestic issues (secession, growing middle class as well as growing poverty), and the border dispute that weakens a potentially very strong alliance between those two.

This article aims to analyse, why the notion of an US decline might be premature, for once due to its continuing domination of crucial elements and secondly due the potential shortcomings of the contestants. In the course of the article I will firstly introduce the concept of a world hegemon using Modelski's Long-Cycles in Global Politics Model and explain why a potential change of hegemony might be imminent. Secondly, while using a pragmatic study method and relying on secondary sources, the article will examine the hinted issues of the contestants. Hereby, a larger focus will be put on China since I consider the domestic problems of both countries as similar and deem China's chances to be a real challenger for more likely. At last, the article will outline why the US' role is not declining at all within the next decades and possibly in the next century and therefore most projections of the 'Chinese century' (Fishman, 2004) might have been premature. Here, (1) the future independence of natural resources, (2) the domination of the world seas, (3) the continuous contestation of the Rimland and at last (4) the control over the Global Commons will be brought forward.

\section{Theory section: $\boldsymbol{A}$ World Hegemon}

At first, a short explanation of the world hegemon concept. This idea is based around George Modelski's concept of 'Long-Cycles in Global Politics' (1987). According to that model we can observe that a critical element of world politics in the modern era is the rise, decline and succession of world powers (Portugal/Spain, Dutch Republic, Britain Twice, and the United States), which has been occurring in intervals of about 80-120 years (1987:3). Each transition has been on an occasion for contested challenge, which puts the US' claim for hegemony around the First or the Second World War when they detached Britain from the leading position. Modelski states further that the world power is equipped with the single leadership in global politics, which is based on the global reach (command of the sea), the leading economy, an open society (democratic potential and also the capacity to forge coalitions within and without political compliance) and the ability to respond to world opinion with innovative policies (Modelski, 1987:10). 
Some might argue that the United States does not fulfil all of these criteria and they are therefore already headed south. However, in the analysis below we will see that the US is clearly in control of these factors and therefore very likely to be able to hold to its hegemonic position. Nevertheless, according to Modelski's model the challenge of the US' supremacy looms in the very near future and is therefore a worthy field of research.

\section{Challengers}

Now to the possible contestant before other factors that speak for a continuation of US supremacy will be scrutinized. It has been established, that a possible contestant can only rise out of the Asian continent. This thesis has found regular approval latest since Jim O'Neill's coined the term BRICs in 2001 and predicted an economical power shift towards the second-tier nations within the next 50 years (2001). O'Neill predicted that based on total GDP these four nations (Brazil, Russia, India and China) will be wealthier than most of the current major economic powers. These predictions are based on the annual growth rates of the national economies in which regards especially China and India stick out with rates of 5.6\% respective $5.9 \%$ (in 2010). Considering, that these growth rates stay considerable stable China is expected to overtake the U.S. as the leading economic power in 2032 (Dadush and Stancil, 2010:10). This is of course, one of the main arguments to proclaim China as the most likely contestant. Other ideas revolve around a BRIC coalition that will ultimately challenge the U.S. and lead us towards a multipolar world.

\section{Domestic Issues}

There is no doubt that the rapidly growing economies of the BRIC (and also other non-G7 nations) will equip them with greater power to influence the current order. Albeit, China and most potential BRIC based coalitions have some growing pains to overcome before they constitute a real threat to the United States. Looking for example at China (note that similar problems apply for India) - the main competitor - we would have to consider the political instability of this vast country. Susan Shirk calls this 'internal fragility' (2013:3) which is caused by domestic threats such as rapid economic rise, social inequality, environmental damage and government corruption. Additionally, Beijing faces domestic problems with secessionist movements and the maintenance its political legitimacy $(\mathrm{He}, 2014)^{4}$. Chinese officials have realized that the communist mantra will not anymore keep the population in line and are now promoting a mixture of ancient Chinese

4 The official communist ideology does counter the current capitalist economy, which also questions the justification for the one-party rule. 
philosophy and nationalism to remain in power. Naturally, this is a process that cannot be done overnight and does furthermore heavily contradict with claims and ideas of secessionist regions such as Xinjiang, Tibet and Inner Mongolia (Lee, 2014). The Han idea and the secessionist movements are hereby highly linked since more secessionist activity will be answered with an increased focus on Han nationalism and an increased focus on Han nationalism will increase secessionist activities vice versa. Lee points out further that it looks like that Han-Nationalism indeed brought some positive effects to the Chinese situation (2014:5). Namely, the social construction of $\mathrm{Xi}$ 's political legitimacy in the power transition, which showed that China's confidence to get involved in international relations grew even though being equipped with its own political system and the one-party rule. This development is especially visible to China's population and enhances political credibility and internal stability (Lee, 2014:5). Han-Nationalism was also able to hide the biggest domestic problems such as housing prices, unemployment issues, income inequality, corruption and people's mistrust toward the local governments, by promoting anti-corruption campaigns and directing the media spotlight to great national achievements and reshuffles national priorities more in favour of the government (Lee, 2014:5). However, this is not the whole story. A major negative effect is the above already mentioned aggravation of the internal ethnic conflicts (Lee, 2014:5). HanNationalism does not at all appeal to the Islamic Uyghur people. In these areas it does not have the ability to hide away the socioeconomic shortcomings. the pervasive nationalistic sentiments activate Uyghur jihadist even more which already resulted in multiple bloodshed and nationwide terrorist attacks which extremely threatens China's internal stability (Lee, 2014:5).

Another domestic problem constitutes the high poverty rate. $10 \%$ of the population lives in extreme poverty (under $1.08 \$ /$ day), even though China managed to decrease this number heavily between 1981 and 2004 when it sunk from 64\% to aforesaid 10\% (Chen and Ravallion, 2008:2). But these numbers include only the very poorest. According to the World Bank around $28 \%$ of the population has under $2 \$$ a year (2009). That means even if the predicted dramatic increases of total GDP occur the GDP per capita in the US will be still three times that of China and eight times that of India (Dadush and Stancil, 2010:11). This discrepancy arguably speaks essentially for a stronger U.S. economy. Beyond that, a growing GDP/capita usually goes along with the process of democratization (Wucherpfennig and Deutsch, 2009:2). The study says that, if the middle class grows and the monetary inequality within a country shrinks, experience suggests that democratic developments are about to start. Even though this theory might lack enough proper examples to fully support it, it cannot be denied that a 
bigger middle class, with more access to education, travel and leisure has the potential to develop regime antagonistic ideas and pursue those. The call for democracy and liberal rights will most probably lead to public discussions, claims and form an inner problem that needs to be considered and could conceivably question the leadership and then again cater for internal instability.

At last, China's immense environmental problems need to be considered. The causes are on hand found on the extreme exploitation of its natural resources, due to the rapid economic development. The supply and demand for natural resources got heavily out of balance and will not only slow down the economic development in the future but obviously also creates environmental problems. The other factor for the environmental issues are to be found in the rapid urbanization of China. At this point approximately $40 \%$ of China's population lives in a city $(1980: \sim 20 \%)$ and the ongoing urbanization rate is $1 \%$, which means that 13 million people move to a city annually (Fu, et al., 2007). Both of these circumstances are co-responsible for China's highly polluted air, water shortage and contamination and are in general a damage to human health, create social conflicts and economic loss (Fu, et al., 2007). To be quite clear, a lot of people die every year from the shortage of clean water, from indoor air pollution $^{5}$, from food shortcomings or intoxication (e.g. Mercury). Environmental deterioration is further one of the main reasons for social unrest ( 51,000 disputes in 2005) and the economic losses due to pollution and ecological damage are estimated to be $7-20 \%$ of the annual GDP (Fu, et. $A l$, 2007). These domestic problems are only a handful of issues China has to solve in the next years and decades to not let unstable domestic politics interfere with the international rise.

\section{Sino-Indian Border}

Potential domestic problems aside there are other issues that might compromise the chances for the dominance of a BRIC-based coalition. One of the biggest doubts arises when we examine the inter-BRIC connections of its two most important members. Yes, the BRICS countries (South-Africa was included in 2010) formed a formal association that not only promotes and encourages the economic, political and cultural cooperation between these nations but also the idea of a multipolar world (Laïdi, 2012). However, the association is far away from being a political united and influential body similar to the European Union. At this point it would be unwise to state that the political cooperation inside this group cannot increase towards an EU

$5 \quad$ A problem in rural China, where highly polluted biomass and coal is used to heat or cook inside (Fu, et al.,2007). 
like level, especially considering the young age of the association, but some disagreements between the members might aggravate the process and eventually BRICS's power. However, arguably one of BRICS strengths is its regional outspread and the possibility to act trans-regional. One of its biggest weaknesses on the other hand is based on the proximity of its two main players. It is most important for a strong BRICS coalition that China and India are able to eliminate their border disputes (including military incursions). The reasons for the ongoing conflict might be found in the internal problems of both states. Fravel argues that if leaders face internal threats they are very likely to use their foreign policy to deviate these (2005:52). Persisting territorial disputes are exactly the right issue to focus on. It seems unlikely that these disputes will come to an end in the near future, since increased cost connected with an active conflict, its escalation and the military defeat would most likely cause more internal risks. ${ }^{6}$

Furthermore, it is necessary that China cuts its growing ties with India's archenemy Pakistan and stops (or at least reduces) its military and economic activities in the Indian Ocean/South Chinese Sea (String of Pearls). Afridi and Bajoria describe the relationship between China and Pakistan not only as mutually beneficial but also as a strategic hedge against India (2010). China has been one of Pakistan's major arms supplier and collaborated in military personnel training, joint exercises and intelligence sharing (Afridi, Bajoria, 2010). However, at this point times might change, with China becoming more and more aware that its Uyghur problem might be highly connected with Pakistan. The increasing level of extremism inside of Pakistan, which does not only lead to recruitment of Uyghur fighters but also created a safe haven for Uyghur jihadists in Pakistan's tribal areas, makes Beijing warry (Afridi, Bajora, 2010). Sino-Pakistani cooperation is also traceable in China's String of Pearls, which has been described by Pehrson as:

'[a] manifestation of China's rising geopolitical influence through the efforts to increase access to ports and airfields, develop special diplomatic relationships, and modernize military forces that extend from the South China Sea through the Strait of Malacca, across the Indian Ocean and on to the Arabian Gulf' (2006:1).

The pearls are used by China to exert great power of the ocean and its sea lines of communication (SLOCs) which brings economic advantages to China but also threatens the regional demands of India (e.g. Khurana,

6 Since the upkeep of these disputes might actually be beneficial to both regimes it is questionable if their existence actually decreases or blocks the cooperation of India and China. In fact, this condition might actually speak for the exact opposite and for a sort of mutually beneficial cooperation. 
2008). Beyond that, it creates a security dilemma for the Indian state. It is mostly based on the deep-rooted suspicion between these two states and the Chinese ties with other South-Asian and Indian Ocean states. A security dilemma usually arises when one state cannot provide its own security without searching for a superior power to protect it (Garver, 2002:1). Observing India's recent behaviour - seeking regional or even international partners in the form of Japan (e.g. Naidu, 2005) and the US ${ }^{7}$ - which on one hand could relieve the security concerns but on the other hand heat up the relationship with China as a traditional Japan antagonist.

The Cross-linked alliances and partnerships all around the Easternand South-Asian region seems to be the biggest problem and powder barrel of an effective cooperation between the two continental Asian major powers. National interest and power play are still dictating the daily politics and we can observe partnerships that are mostly based on the containment of the other instead of mutual benefits. ${ }^{8}$ It does not seem like this situation will change in the near future and both states are to be viewed as an independent player. Nevertheless, a harmonized South-Asian alliance would constitute an immense threat to the current world order. However, the possibility of a power shift might be not as obvious and inevitable as commonly understood.

\section{United States of America}

There is not only scepticism appropriate when it comes to the rise of US' challengers but also to the arguable inevitable decline of the United States' power. In the following four arguments will be outlined, that describe why the US has a rather good chance of prolonging its stand as the world hegemon for at least another century.

\section{The Future Independence of Natural Energy Sources}

A concern of US policymakers has been since the Second World War the country's supply of gas and oil. The need made its foreign policy weaker and more predictable and has been clearly expressed in the foreign policy approach to the Middle East in the last century (Shwadran, 1985). However, with the Shale Revolution and other technical achievements the US will be (and does already) increase domestic oil and gas mining. Especially the untouched amount of gas (estimations start at 11 trillion cubic meters), which will be able to produce electricity and to substitute gasoline and diesel in vehicles, will become a powerful resource (Deutch, 2011:89). This will also make their natural resources supply independent from other states and does

7 Other options are e.g. a democratic alliance between India, Japan, USA and Australia, or India teaming up with India to pressure the common enemy Pakistan (as described in: Tow and Acharya, 2007).

$8 \quad$ Though, where is the difference here? 
decrease the importance of classical gas supplying countries such as Iran, Qatar, Russia, Saudi Arabia and Turkmenistan (Deutch, 2011:82). This also means another increase in the relevance of the United States. Beyond, that it will lead to a stabilization of the world oil price (Brown and Yücel, 2013). Out of this the US' foreign policy can finally act unattached from the fear of supply shortcomings. This will not only lessen the vulnerability of its economy to oil price shocks but also change its foreign policy approach, where it can act more aggressive and shift its focus and priorities, away from the Middle East and Europe - where Russia does not necessarily will continue to dominate the European gas market if the US could emerge as a new supplier - towards the new battlefield in the Pacific region.

\section{The US' Domination of the World's Seas}

'Great is the power of the country that controls the sea'. Those were the words that Thucydides put in the mouth of Athens' great commander Pericles in the eve of the Peloponnesian War. This ancient Greek predicate shall be proven correct in the following centuries and millennia in which sea domination has not only been the guarantor but main indicator for world rule. In charge of the world's seas a power commands the mobility to project and protect power all over the globe (see also: Mahan, 1890). In our times, no vessel is better made for this endeavour than an aircraft carrier, which tend to appear at the coasts of states that are acting not conforming to the U.S. suggestions. This is where the magnitude of the U.S. dominance becomes highly visible. According to Globalsecurity.org, the US fleet does not only boast 19 aircraft carriers (the rest of the world has 12 combined) but by far the largest and technologically advanced (2014). China, the main competitor will have two models on the water by 2020 . However, one carrier is an ex-Soviet model that has been purchased from the Ukraine in 1998 and started its sea trials in 2011 after lengthy refurbishing and its newest model is already obsolete before its maiden voyage (Roggeveen, 2018). At the moment the United States is building three new nuclear-powered aircraft carriers which are all scheduled to be commissioned by 2025 (O'Rourke, 2014). According to the Congressional Research Service every ship will cost between \$11Billion and \$13Billion and take between seven and eight years to be constructed (O'Rourke, 2014). This will not only cement the dominance of the US Navy but shows how costly and tedious an aircraft carrier program of a competitor would be to overtake the United States in this sector.

\section{US' Reinstated Activity in the Rimland}

With the complete withdrawal of American troops from Afghanistan the US is officially giving up its presence and military influence in the region. Afghanistan, devastated from the lengthy war will be left behind as a 
failed state and it is expected that another big power (China) will interlude and benefit immensely from the won influence in the region. The US' lost interest in the region could have arguably had an influence on the though long debated but initially did not execute an intervention in Syria, which would have prolonged US influence. However, speculations on this can be put to rest, with the news of the US troops landing in Syria (Gibbons-Neff et al., 2018). However, why is this region so important if, as I pointed out above, the United States is not interested anymore in the oil reserves and therefore helpful influence in the region? An explanation can be found in Spykman's words: 'Who controls the Rimland controls Eurasia, who controls Eurasia controls the contents of the world' (1944, italics added). Afghanistan and the Middle East are a part of the Rimland, which extends from Europe's coastlines over the Balkans to South-East Asia. One might argue that the US' Foreign policy after WWII was based on keeping other powers out of this territory (from the Korean War, to Vietnam, Turkey's admission to NATO, the Balkan wars and multiple involvement in Afghanistan and Iraq) to ensure that nobody else obtains this favourable position. Nevertheless, the recent fading involvement might be put aside considering the recent news mentioned above. It has been pointed out that the hotbed of the group lay in several other challenges of the region - the ongoing civil war in Syria being the biggest - and without addressing them other counter measures are going to be unsuccessful (Watts, 2014). ISIS and the Assad Regime have already shown that the U.S. strategies do not have the desired effects and with extended duration of the conflict it seems rather likely that the U.S. and its allies need to address the roots of the problem. This does not only ask for boots on the ground but for a long-lasting mission which provides the US renewed presence and influence in the region.

\section{US' control over the Global Commons}

The Global Commons are typically described as international or global resource domains in which common resources are found and no clear territorial ownership is established (see e.g.: Buck, 1998). They classically include open waters, shared natural resources (deep-sea), the polar regions, the atmosphere, outer space and most recently added cyberspace. Since the successful lunar race in the 1960's the US holds a clear advantage in sea, air and space and have the unrestricted freedom of action. When the internet started its commercial success in the late 20th century nobody thought it seemed unimaginable that a single power could control this immense new landscape. After the revealing of Edward Snowden in the summer of 2013 we know that it is possible. He showed us not only that the USA is capable of controlling and saving every internet connection that runs through their territory but also that the majority of the commercial internet connections 
indeed run through the US mainland (Greenwald, 2013). Hereby, it does not matter if this is based on the monopoly position of American multimedia concerns since the physical linkages are under government control (it also does not matter if this was a coincidence or planned and supported by the US government). For clarification this means, that every message send through Facebook, every email addressed to a Gmail account and every file saved in iCloud (to only name a few) will first make its way through an submarine cable into a server in the United States and from there to the recipient (Gellman and Poitras, 2013). Snowden's revelations showed us that the debate on a possible New Great Game on the internet supremacy is not only very out of time but already decided. Note further, that the domination of the cyberspace is even more empowering in our extremely technologized world that demands a $24 / 7$ connection with the internet.

\section{Old, New, Changing Hegemony?}

Not many will argue that the U.S.A. cemented themselves as the driving force of global politics. Small countries look up to them, await advise and that they lead the way. Greater powers have grown wary of the U.S. power but are more and more able to affront them on certain fields. At this point it is also no secret to anyone that Asia does not only outnumber them by population but will most certainly overtake the U.S. position as the leading economy in the next 20-30 years.

However, this is not the only factor, that is deciding when it comes to identifying the world hegemon. As pointed out above, the economic supremacy of China (and India) might not be as certain as commonly presumed. There are several domestic issues to overcome, which when unsolved will not only slow down the necessary developments but might even jeopardize those by the endangerment of internal stability, the legitimacy of the leadership and also the livelihood of the population. In addition, the biggest threat to the US supremacy would be constituted by a harmonic cooperation of the two biggest Asian players. However, due to a history of distrust, ongoing border disputes, security restraints and an ongoing non-compliance of partnerships and foreign policy India and China are not coming together in the near future.

But the continuation of the US supremacy is not solely based on the shortcomings of the contestants. As stated above, the US dominates every other very important aspect that is crucial for the hegemony. They will continue to remain the strongest military power by a great margin and to control the Global Commons (especially sea and cyberspace). It is most likely that their fossil energy supply for the next century is secured with resources on their own soil and ongoing tensions and conflicts in the Middle East will secure their influence and involvement in the Rimland. Apart from 
these findings it is traceable that a transition period of global power is lying ahead. In fact, the US itself is aware of this and the recent focus away from a European towards a more Pacific oriented policy only proves this conjuncture (e.g. Clinton, 2011).

Concluding, the rise of other powers is undeniable - but so is the continuing domination of the United States of America. Challenge(r)s for its supremacy are imminent, but it is not very likely that the second half of the $21^{\text {st }}$ century will be dominated by another power than the United States. If we look back at Modelski's model a repeat, as seen with Britain in the 19th century, is very likely. The only other plausible option, is the notion of a $\mathrm{bi} /$ multipolar world, very similar to the Spanish/Portuguese Period in the $16^{\text {th }}$ century where two powers share the hegemonic role and divide power and influence amongst each other (Modelski, 1973). This scenario seems especially likely if the U.S. decides to focus more on its domestic policies (as demanded by a lot of its citizens), increases the Trans-Pacific cooperation even more and if the Asian powers are able to adapt to their upcoming challenges. If so, a shared US/Asia(China) hegemony might be able to take the current position of the United States..

\section{References:}

1. Afridi, J. Bajoria, J. "China-Pakista Relations" Council on Foreign Relations" (06.07.2010) Retrieved from: http://i.cfr.org/china/chinapakistan-relations $/ \mathrm{p} 10070$

2. Brown, S.P.A., Yücel, M.K. "The Shale Gas and Tight Oil Boom: U.S. States' Economic Gains and Vulnerabilities." Council on Foreign Relations (October 2013).

3. Buck, S.J. (1998) "The Global Commons. An Introduction", Routledge, New York.

4. Chen, S., Ravallion, M., "China is Poorer than we Thought, But No Less Successful in the Fight against Poverty" Policy Research Working Paper 4621 (May, 2008).

5. Clinton, H. (2011) “America's Pacific Century. The Future of Geopolitics Will Be Decided in Asia, not in Afghanistan or Iraq, and the United States Should Be Right at the Center of the Action" Foreign Policy, Washington, Issue 189: 56-63.

6. Dadush, U., Stancil B. (2010) "The World Order in 2050." Policy Outlock (April, 2010): 1-29.

7. Deutch, J "The Good News about Gas. The Natural Gas Revolution and its Consequences" Foreign Affairs (January/February 2011): 8293.

8. Fishman, T.C. "The Chinese Century" The New York Times (04.07.2004), retrieved from: 
https://www.nytimes.com/2004/07/04/magazine/the-chinesecentury.html (04.06.2018)

9. Fravel, M.T. "Regime Insecurity and International Cooperation. Explaining China's Compromises in Territorial Disputes" International Security Vol. 30, No.2 (Fall, 2005): 46-83.

10. Fu, B. Zhuang, X., Jiang, G. Shi, J., Lü, Y. "Environmental Problems and Challenges in China" Environmental Science and Technology (November 15 2007): 7597-7602.

11. He, Baogang (2014) "China's National Identity: A Source of Conflict between Democracy and State Nationalism", in: Leong H.L., Shaoguang, W. (eds.). "Nationalism, Democracy and National Integration in China (2012), Routledge.

12. Hung, Ho-Fung (2017) "Hegemonic Crisis, Comparative WorldSystems, and the Future of the Pax Americana" Journal of WorldSystems Research, Vol. 23, Issue 2: 637-648.

13. Garver, J.W. "The Security Dilemma in Sino-Indian Relations" India Review (01.10.2002): 1-38.

14. Gellman, B., Poitras, L. (07.06.2013) "U.S., British Intelligence Mining Data from Nine U.S. Internet Companies in Broad Secret Program" Washington Post, retrieved from: https://www.washingtonpost.com/investigations/us-intelligencemining-data-from-nine-us-internet-companies-in-broad-secretprogram/2013/06/06/3a0c0da8-cebf-11e2-8845d970ccb04497_story.html?noredirect=on\&utm_term=.f1855061c7c1 (11.06.2018).

15. Gibbons-Neff, T., White, J., Botti, D. (11.04.2018) "The U.S. Has Troops in Syria. So Do the Russians and Iranians. Here's Where." New York Times, retrieved from: https://www.nytimes.com/interactive/2018/04/11/world/middleeast/s yria-military-us-russia-iran.html (11.06.2018).

16. GlobalSecurity.org "World Wide Aircraft Carriers." Retrieved from: http://www.globalsecurity.org/military/world/carriers.htm (04.06.2018).

17. Greenwald, A. (06.06.2013) "NSA Collecting Phone Records of Millions of Verizon Customers Daily" The Guardian, retrieved from: https://www.theguardian.com/world/2013/jun/06/nsa-phone-recordsverizon-court-order (11.06.2018).

18. Khurana, G.S. (2008) "China's 'String of Pearls' in the Indian Ocean and Its Security Implications" Strategic Analysis, Vol 32, Issue 1:139. 
19. Komlosy, A. (2016) "Prospects of Decline and Hegemonic Shifts for the West" Journal of World-Systems Research, Vol. 22, Issue 2: 463483.

20. Laïdi, Z. (2012) "BRICS: Sovereignty Power and Weakness" International Politics, Vol. 49: 614-632.

21. Layne, C. (2009) "The Waning of U.S. Hegemony - Myth or Reality? A Review Essay" International Security, Vol. 34, Issue 1: 147-172.

22. Lee, R. (2014) "Han Nationalism in China" Al Jazeera Center for Studies: $1-9$.

23. Mahan, A.T. (1890) "The Influence of the Sea Power Upon History, 1660-1783", London, Methuen.

24. Mandelbaum, M. (2006) "The Case for Goliath: How America Acts as the Worlds Government in the $21^{\text {st }}$ Century, Public affairs, New York.

25. Meernik, J.D. (2004) "The Political Use of Military Force in US Foreign Policy", Ashgate, Burlington.

26. Modelski, G. (1987) "Long-Cycles in Global Politics.", MacMillan Press, London, 1987

27. Naidu, G.V.C. (2005) "India-Japan Relations. Towards a Strategic Partnership" China Report, Vol 41, Issue 3: 327-330.

28. NBC News "Obama Administration Says U.S. is at War with ISIS", Retrieved from: http://www.nbcnews.com/storyline/isisterror/obama-administration-says-u-s-war-isis-n202336 (04.06.2018).

29. O'Rourke, R. (2018) "Navy Ford (CVN-78) Class Aircraft Carrier Program: Background and Issues for Congress." Congressional Research Service.

30. Pehrson, C.J. (2006) "String of Pearls: Meeting the Challenge of China's Rising Power across the Asian Littorial" Strategic Studies Institute.

31. Roggeveen, S. (25.04.2018) "China's New Aircraft Carrier Is Already Obsolete" Foreign Policy, retrieved from: http://foreignpolicy.com/2018/04/25/chinas-new-carrier-is-alreadyobsolete/ (11.06.2018).

32. Shirk, S.L., Myers. J.J. (2013) "China: Fragile Superpower: How China's Internal Politics Could Derail its Peaceful Rise" Carnege Council for Ethics in International Affairs.

33. Shwadran, B. (1985) "The Middle East, Oil and the Great Powers", United States.

34. Spykman, N.J. "The Geography of the Peace", Harcourt Braze, 1944.

35. Tow, W.T., Acharya, A. (2007) "Obstinate or Obsolote?: The US Alliance Structure in the Asia-Pacific" Department of International 
Relations, Research School of Pacific and Asian Studies, Australian National University.

36. Wallerstein, I. (2003) "U.S. Weakness and the Struggle for Hegemony" Monthly Review-New York, Vol. 55(3): 23-29.

37. Watts, C. (18.09.2014) "Seven Flaws in the US Strategy to Counter ISIS." Foreign Policy Research Institute. Retrieved from: http://www.fpri.org/geopoliticus/2014/09/seven-flaws-us-strategycounter-isis (04.06.2018).

38. World Bank "GDP Growth (Annual \%)", Retrieved from: http://data.worldbank.org/indicator/NY.GDP.MKTP.KD.ZG (04.06.2018)

39. World Bank "Poverty Headcount Ratio at $\$ 2$ a day (ppp) (\%of population)", Retrieved from: http://data.worldbank.org/indicator/SI.POV.2DAY/countries/CN?dis play=graph (22.09.2014).

40. Wucherpfennig, J., Deutsch, F. "Modernization and Democracy: Theories and Evidence Revisited." Living Reviews in Democracy, Vol.1 (2009): 1-9 